\title{
Acute intermittent porphyria in identical twins
}

\author{
J. C. Ferguson \\ M.B. (Glasg.), M.R.C.P.E., M.R.C.P.G. \\ A. D. Beattie \\ M.B. (Glasg.) \\ S. G. MCALPINE \\ M.D. (Glasg.), F.R.C.P.G., M.R.C.P. \\ H. CONWAY \\ B.Sc., M.B. (Glasg.), F.R.C.P., F.R.C.P.G. \\ Royal Alexandra Infirmary, Paisley, Scotland, and Department of Medicine, University of Glasgow, \\ Western Infirmary, Glasgow, W.1, Scotland
}

\section{Patient 1}

A 19-year-old female was initially admitted to the surgical unit of the Royal Alexandra Infirmary on 30 January, 1966. Her complaint was of 3 days' abdominal pain, vomiting and constipation. The constipation had been present for several days prior to the other symptoms. The first clinical impression was of simple constipation and she was treated with purgatives; pethidine was given for the abdominal pain. On 1 February she had an epileptiform seizure, apparently her first, and a few days later, when it was discovered that her twin sister was suffering from a similar illness, a more detailed family history revealed her to be a cousin of a known case of acute intermittent porphyria. The diagnosis was quickly established by testing the urine for porphobilinogen with Ehrlich's reagent.

On transfer to the medical wards, her history was reviewed and it became apparent that the illness dated from her attendance at a party 3 days previously when she took alcohol for the first time. During the next 2 days $50 \mathrm{mg}$ of butobarbitone were ingested on four occasions because she felt unwell.

On examination she was a thin, pale young woman, normally developed, afebrile but with a persistent sinus tachycardia of $120 / \mathrm{min}$. The cardiovascular system was otherwise normal, the blood pressure being $120 / 90 \mathrm{mmHg}$. On neurological examination there was weakness of all limbs and all tendon reflexes were absent, and there was no sensory abnormality. Respiratory and alimentary systems were normal.

Her subsequent progress was one of gradual recovery and she was discharged on 5 March, 1966, apparently well, the muscle weakness and reflexes having returned to normal. When seen in August 1969 , she was symptom-free and physical examination was completely normal. The important laboratory investigations are summarised in Table 1.
TABLE 1. Laboratory investigations: Case 1

\begin{tabular}{|c|c|c|c|}
\hline 1966 & Feb. 12 & Mar. 2 & Mar. 3 \\
\hline $\begin{array}{l}\text { Urinary porphobilinogen }(\mathrm{mg} / 24 \mathrm{hr}) \\
\text { Urinary uroporphyrin }(\mu \mathrm{g} / 24 \mathrm{hr}) \\
\text { Urinary coproporphyrin }(\mu: \mathrm{g} / 24 \mathrm{hr}) \\
\text { Faecal coproporphyrin } \\
\text { ( } \mu \mathrm{g} / \mathrm{g} \text { dry weight) }\end{array}$ & $\begin{array}{r}79 \\
960 \\
490\end{array}$ & 52 & 4 \\
\hline
\end{tabular}

\section{Patient 2}

This young girl was less ill than her twin sister and was admitted to the medical unit of the Royal Alexandra Infirmary on 8 February, 1966, having had an illness for 2 weeks characterized initially by myalgia, cough, sore throat and lower abdominal pain. Total constipation for several days was also a feature. She later developed numbness of the thighs and legs.

Like her sister, the onset of symptoms dated from the same party at which she also had taken alcohol for the first time. Again, like her sister, she had taken butobarbitone in a dose of $100 \mathrm{mg}$ on two occasions.

On examination she was a thin pale young woman, identical in appearance to her twin. She had a persistent sinus tachycardia. The cardiovascular system was otherwise normal, blood pressure $130 / 90 \mathrm{mmHg}$. Neurological examination revealed diminished muscle power in her legs and all tendon reflexes were absent. Sensation was unimpaired. Examination of respiratory and alimentary systems was normal. Serial laboratory investigations are listed in Table 2. She too has had no recurrence of symptoms since the initial illness.

\section{Further investigations \\ Family studies}

The diagnosis was reached by reason of a known relationship to a case of porphyria. Further investigation showed that three relatives, a paternal aunt, 
TABLE 2. Laboratory investigations: Case 2

\begin{tabular}{lrrrrc}
\hline 1966 & Feb.11 & 21 & 26 & 27 & Mar. 1 \\
\hline $\begin{array}{l}\text { Urinary porphobilinogen } \\
\text { (mg/24 hr) }\end{array}$ & 60 & 57 & 44 & 45 & \\
$\begin{array}{l}\text { Urinary uroporphyrin } \\
\text { ( } \mu \mathrm{g} / 24 \mathrm{hr})\end{array}$ & 1360 & & & & \\
$\begin{array}{l}\text { Urinary coproporphyrin } \\
(\mu \mathrm{g} / 24 \mathrm{hr})\end{array}$ & & & & & \\
$\begin{array}{l}\text { Faecal coproporphyrin } \\
\text { ( } u \text { g/g dry weight) }\end{array}$ & 340 & & & & \\
$\begin{array}{l}\text { Faecal protoporphyrin } \\
(\mu \mathrm{g} / \mathrm{g} \text { dry weight) }\end{array}$ & & & & & 9 \\
\hline
\end{tabular}

uncle and cousin, died in circumstances highly suggestive of acute intermittent porphyria and a fourth case described by Heggarty and Ferguson (1968), a paternal cousin, has since died of the effects of porphyria. The family tree is shown in Fig. 1. The uncle died of a paralytic ileus after an operation for acute abdominal pain, the aunt in a mental institution and the cousin of respiratory paralysis. Six other members of their father's family have since been traced and shown to have latent porphyria by means of raised urinary porphyrins, $\delta$-aminolaevulic acid and porphobilinogen.

The twins have identical blood group antigens, namely A, B; CCDe; MMS; P, (-); kk; Lu(a-); Le(a-b-); Fy $(a+)$. An interesting and rare variant of chromosome I was demonstrated in both patients; one homologue of this chromosome showed extreme elongation at the secondary constriction site. There was no evidence of chromosome breakage or rearrangements and the karyotype was within normal limits. The chromosome abnormality has not been shown in any of the relatives tested.

\section{Effect of alcohol}

The patients were admitted on 19 August, 1968 to the metabolic ward of the Department of Medicine, Western Infirmary, Glasgow. Both were given exactly the same ward diet. Daily estimation of erythrocyte porphyrins was carried out and all urine and faeces was collected for 6 days for measurement of porphyrin output. Both patients were clinically well during the period of investigation.

In view of the possible precipitation of symptoms in both cases by the ingestion of alcohol, we investigated the effect of alcohol on porphyrin production in one twin, using the other as a control. After 3 control days, one of the patients, Case 2, was asked to drink $50 \mathrm{ml}$ of whisky (16 $\mathrm{g}$ absolute alcohol), and collections were taken for a further 3 days. Tables 3 and 4 show the urinary porphyrins, $\delta$-aminolaevulic acid and porphobilinogen on each of the 6 days of collection. The only change noted was a tenfold increase in excretion of urinary coproporphyrin in Case 2 on the second day after ingestion of alcohol. The rise is statistically significant $(P<0.01)$.

\section{Comment}

Kehoe, Rudensky \& Reynolds (1957), described

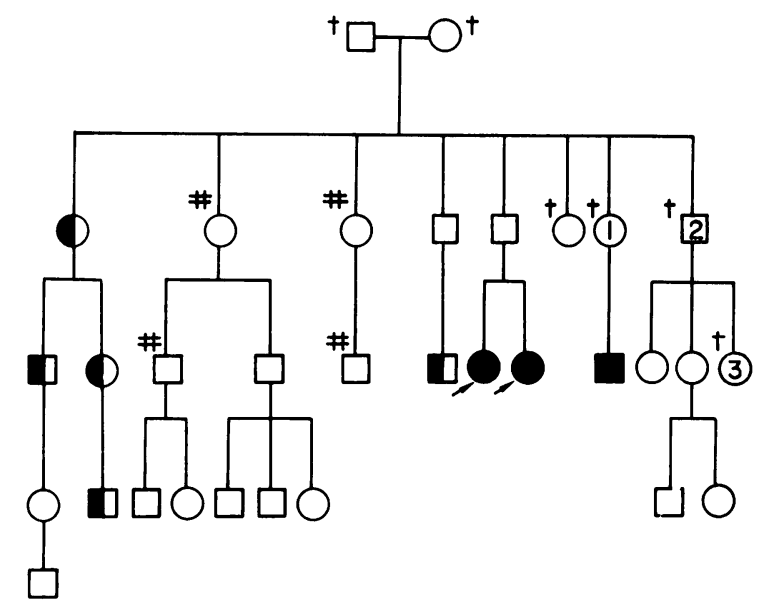

$$
\begin{aligned}
& \text { Died prior to study } \\
& \text { 1. Died in mental Institution } \\
& \text { 2. Died of paralytic lleus after } \\
& \text { operation } \\
& \text { 3. Died of resplratory paralysis }
\end{aligned}
$$

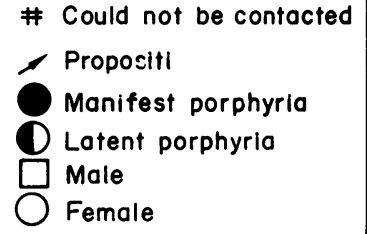

Fig. 1. Family tree of the twins. 
TABLE 3. Urinary porphyrins excretion in Case 1 during period of study

\begin{tabular}{|c|c|c|c|c|c|c|}
\hline & $\begin{array}{c}\text { Day } \\
1\end{array}$ & $\begin{array}{c}\text { Day } \\
2\end{array}$ & $\begin{array}{c}\text { Day } \\
\mathbf{3}\end{array}$ & $\begin{array}{c}\text { Day } \\
4\end{array}$ & $\begin{array}{c}\text { Day } \\
5\end{array}$ & $\underset{6}{\text { Day }}$ \\
\hline Urinary coproporphyrin $(\mu \mathrm{g} / 24 \mathrm{hr})$ & $655 \cdot 6$ & $601 \cdot 0$ & $629 \cdot 7$ & $651 \cdot 2$ & $686 \cdot 1$ & $654 \cdot 7$ \\
\hline Urinary uroporphyrin $(\mu \mathrm{g} / 24 \mathrm{hr})$ & $1379 \cdot 5$ & $969 \cdot 1$ & $917 \cdot 0$ & $1050 \cdot 3$ & $977 \cdot 1$ & $729 \cdot 9$ \\
\hline$\delta$-aminolacvulic acid $(\mathrm{mg} / 24 \mathrm{ht})$ & $25 \cdot 2$ & $15 \cdot 1$ & $24 \cdot 4$ & $12 \cdot 2$ & $19 \cdot 1$ & 16.9 \\
\hline Porphobilingen (mg/24 hr) & $71 \cdot 0$ & $57 \cdot 0$ & $63 \cdot 2$ & $53 \cdot 1$ & $50 \cdot 1$ & $50 \cdot 6$ \\
\hline
\end{tabular}

TABLE 4. Urinary porphyrin excreticn in Case 2 before and after alcohol

\begin{tabular}{|c|c|c|c|c|c|c|}
\hline & \multicolumn{3}{|c|}{ Before alcohol } & \multicolumn{3}{|c|}{ After alcohol } \\
\hline & $\begin{array}{c}\text { Day } \\
1\end{array}$ & $\begin{array}{c}\text { Day } \\
2\end{array}$ & $\begin{array}{c}\text { Das } \\
3\end{array}$ & $\begin{array}{c}\text { Day } \\
4\end{array}$ & $\begin{array}{c}\text { Day } \\
5\end{array}$ & $\begin{array}{c}\text { Day } \\
6\end{array}$ \\
\hline Urinary coproporphyrin $(\mu: \mathrm{g} / 24 \mathrm{hr})$ & $473 \cdot 3$ & $404 \cdot 8$ & $295 \cdot 4$ & $363 \cdot 8$ & $4712 \cdot 0$ & $410 \cdot 7$ \\
\hline Urinary uropoi phyrin $\left(\mu \mathrm{g} / 24 h_{i}\right)$ & $968 \cdot 1$ & $664 \cdot 4$ & 373.6 & $849 \cdot 0$ & $1083 \cdot 0$ & $760 \cdot 2$ \\
\hline$\delta$-aminolaevulic acid ( $\mathrm{mg} / 24 \mathrm{hr}$ ) & $15 \cdot 5$ & $9 \cdot 86$ & $11 \cdot 1$ & $16 \cdot 6$ & $15 \cdot 7$ & $12 \cdot 2$ \\
\hline Porphobilingen (mg/24 h1) & $52 \cdot 5$ & $41 \cdot 0$ & 314 & $49 \cdot 1$ & $40 \cdot 6$ & $39 \cdot 6$ \\
\hline
\end{tabular}

the only previous example of acute intermittent porphyria in identical twins. As in our cases, these two patients were remarkable in that they presented clinically within a few days of each other at the age of 21 years. The homozygotic genetic relationship of our patients is substantiated by the finding of exactly the same blood group antigens. It has recently been suggested by Burchardt, Wichmann \& Zernahle (1968), that an increased number of chromosome breakages may occur in acute intermittent porphyria. We failed to substantiate this finding but we did show that an identical variant of chromosome I was present. 'The significance of this is not known.

The relationship of alcohol to porphyrin metabolism was first demonstrated by Franke \& Fimkemtscher (1935) who showed that the administration of alcohol to healthy men and to chronic alcoholic subjects increased the excretion of urinary coproporphyrin. The clinical relationship of alcohol to porphyria cutanea tarda symptomatica in the cases described by Eales (1963) in South Africa is suggested by the almost invariable finding of chronic alcoholism in patients with this disorder.

In our patients, the role of alcohol as a precipitating agent for the clinical manifestations is obscured by the fact that in both cases barbiturate drugs were taken prior to hospital aomission, though after the onset of symptoms. Barbituraies are of course well documented precipitants of acute intermittent porphyria as Goldberg (1959) has shown. We have demonstrated a significant elevation of urinary coproporphyrin in one of our patients after ingestion of alcohol although the patient remained asymptomatic.
The mechanism by which alcohol influences porphyrin metabolism is not clear. Shanley, Zail \& Joubert (1968) have demonstrated a significant rise in the hepatic level of the rate-limiting enzyme $\delta$ aminolaevulic acid synthetase in rats to whom $5 \mathrm{ml}$ of $20 \%$ ethanol was administered intraperitoneally; this elevation was maximal $3 \mathrm{hr}$ after administration.

\section{Acknowledgments}

Our acknowledgments are due to Professor A. Goldberg for his encouragement and helpful comments, to $\mathrm{Dr} \mathrm{M}$. Ferguson-Smith for the chromosome analysis, and to $\mathrm{Mr}$ G. R. Milne for the blood grouping tests.

\section{References}

BurchardT, U., WichmanN, T. \& Zernahle, K. (1968) Chromosomenveranderungen bei der absuten intermittierenden porphyrie. Klinische Wochenschrift, 46, 438.

Eales, L. (1963) Porphyria as seen in Cape Town. A survey of 250 patients and some recent studies. South African Journal of Laboratory and Clinical Medicine, 9, 151.

Franke, K. \& FimkemtsCher, R. (1935) Die Bedeutung der quantitativen Porphyrinbestimmung mit der Lumineszenzmes sung fur die prufung der Liberfuntkion und fur Ernahrungsfragen. Münchener medizinische Wochenschrift, $82,171$.

GolDBERG, A. (1959) Acute intermittent porphyria.Quarterly Journal of Medicine, 28, 183.

Heggarty, H. \& Ferguson, J.C. (1968) Acute intermittent porphyria with intestinal perforation. Scottish Medical Journal, 13, 293.

Kehoe, E.L., Rudensky, H. \& Reynolds, W.W. (1957) Acute intermittent porphyria in identical twins. Annals of Internal Medicine, 47, 131.

ShanleY, B.C., ZaIL, S.S. \& JouberT, S.M. (1968) Effect of ethanol on liver $\delta$-aminolaevulinate synthetase in rats Lancet, i, 70. 